\title{
Implementasi Peraturan Bupati Purwakarta No. 69 Tahun 2015 Tentang Pendidikan Berkarakter
}

\author{
${ }^{1}$ Faizal Pikri, ${ }^{2}$ Rodlial Ramdhan Tackbir Abubakar, ${ }^{3}$ Nurmilah Adawiyah \\ ${ }^{1}$ Administrasi Publik, Fakultas Ilmu Sosial dan Ilmu Politik UIN Sunan Gunung Djati Bandung; \\ faizalpikri@uinsgd.ac.id \\ ${ }^{2}$ Sekolah Tinggi Ilmu Administrasi LAN Bandung; rodlial.ramdhan@ stialanbandung.ac.id \\ ${ }^{3}$ Administrasi Publik, Fakultas Ilmu Sosial dan Ilmu Politik UIN Sunan Gunung Djati Bandung; \\ nurmilahadawiyah1@gmail.com
}

\begin{abstract}
Education is one of the basic things tha must be obtaned by citizen in every country. This research is motivated by there are complaints from parents who do not have time to prepare food for their children who attend school too late in the morning. However, there are students or teachers who come late and don't break the rules. The purpose of this research is to analyze the implementation of regent regulations related to school hours rules. The theory used in this research is the theory of Edward III which includes communication, resources, disposition, and bureaucratic structure. The research method use is descriptive research reluctant to use qualitative approach. The data collection technique is direct observation, in-depth interview, library study, and documentation. The data analysis technique used is data reduction, data presentation, and conclusion drawing. The result of the study show that the policy of school hours at 06.00 is not appropriate to be implemented. Therefore, some improvements are needed regarding the policy regulations.
\end{abstract}

Keywords: Policy Implementation, Character Education, School Hours rules.

\section{Pendahuluan}

Salah satu daerah yang telah mengimplementasikan tujuan Pendidikan Nasional adalah Purwakarta, yaitu melalui Peraturan Bupati Purwakarta Nomor 69 Tahun 2015 tentang Pendidikan Berkarakter. Tujuan diselenggarakannya pendidikan berkarakter bagi seluruh sekolah di daerah Kabupaten Purwakarta berdasarkan Pergub tersebut adalah sebagai berikut:

1) Sebagai acuan bagi guru untuk membimbing dan mengasuh peserta didik yang termasuk kedalam proses belajar di sekolah;

2) Memberikan pelatihan bagi peserta didik untuk menerapkan pola hidup yang tertib, peduli, mandiri, dan peka terhadap lingkungan sekitarnya;

3) Menjadikan sekolah sebagai saarana untuk membentuk sikap maupun perilaku baik para peserta didik;

4) Membuat suatu hubungan yang harmonis dan bersinergis antara guru dan orang tua peserta didik untuk mewujudkan cita-cita pendidikan; dan

5) Memberikan petunjuk untuk pemerintah di suatu daerah dalam proses perencanan dan perumusan kebijakan khususnya bidang pendidikan yang masuk pada aspek untuk membina mental dan spiritual peserta didik yang terhubung dengan aspek yang bersifat kulikuler. 
Pengukuran implementasi kebijakan berdasarkan Edward III dalam Nugroho (2012: 191) dapat dilakukan melalui 4 variabel, diantaranya:

\section{Variabel Komunikasi}

Komunikasi adalah suatu kegiatan yang dilakukan oleh dua orang atau lebih yang memiliki tujuan untuk menyampaikan informasi kepada orang lain. Dalam hal ini, komunikasi yang dimaksud adalah serangkaian informasi yang disampaikan pemerintah kepada masyarakat mengenai suatu kebijakan yang nantinya akan diberlakukan. Variable komunikasi ini terdiri dari beberapa dimensi yang terdiri dari transmisi, kejelasan, dan konsistensi.

\section{Variabel Sumber Daya}

Dalam proses implementasi kebijakan, tentunya peranan sumber daya sangat penting sebagai unsur pelaksana dari kebijakan yang dibuat. Tenaga ahli yang relevan dan andal sangat diperlukan, karena untuk mengefektifkan suatu kebijakan diperlukan orang-orang yang memilliki kemampuan atau keahlian dalam menjalankan tugas-tugasnya. Unsur dari Sumber Daya tersebut diantaranya adalah a) staf, yaitu jumlah staff yang tidak mencukupi, ditambah staff yang kurang kompeten dalam bidangnya merupakan salah satu penyebab dari gagalnya suatu implementasi kebijakan, b) informasi, yaitu terkait dengan tata cara pelaksanaan kebijakan, artinya implementor harus tahu dengan pasti tentang semua yang harus seorang implementor lakukan ketika mereka mendapatkan perintah untuk melakukan sebuah tindakan, dan informasi tentang data kepatuhann para pelaksana pada regulasi pemerintah yang telah ditetapkan. Implementor harus tahu apakah seluruh pihak yang terlibat dalam kebijakan tersebut patuh terhadap hukum, c) wewenang, yaitu agar perintah dapat dilaksanakan, maka kewenangan haruslah bersifat formal, d) fasilitas, yaitu dalam implementasi kebijakan, fasilitas fisik yang berupa sarana dan prasaran sangat diperlukan untuk menunjang proses pengimplementasian kebijakan.

\section{Variabel Disposisi (sikap pelaksana kebijakan)}

Disposisi diantaranya merupakan karakter yang dimiliki oleh pelaksana seperti memiliki sikap jujur, memiliki komitmen terhadap tugas yang diterimanya, serta tegas dalam pelaksanaan kebijakan. Untuk mencapai hal tersebut dapat dilakukan melalui a) pengangkatan birokrat, yaitu dalam penentuan anggota untuk melaksanakan suatu kebijakan harus mereka yang berdedikasi dalam setiap kebijakan, b) insentif, yaitu dengan memberikan keuntungan atau biaya tertentu dapat menjadi pendorong bagi para pelaksana kebijakan. Hal itu dilakukan dengan tujuan untuk pemenuhan kepentingan seseorang (self interest) dalam suatu organisasi.

\section{Struktur Birokrasi}

Struktur birokrasi merupakan kesesuaian antar organisasi birokrasi sebagai penyelenggara implementasi kebijakan publik. Namun struktur birokrasi seringkali lemah, selain itu kebijakan yang dibuat pun terkadang begitu rumit, sehingga harus ada kerjasama dengan berbagai pihak. Karena, saat tatanan birokrasi tidak teratur pada kebijakan yang telah ada, maka itu akan menjadi penghambat dalam berjalannya suatu implementasi kebijakan.

Dilihat dari latar belakang diatas, maka penelitian ini bertujuan untuk menganalisis implementasi Peraturan Bupati Purwakarta Nomor 69 Tahun 2015 tentang pendidikan berkarakter khususnya mengenai aturan jam sekolah dan bagaimana faktor-faktor yang menjadi pendukung dan menghambat proses implementasi Peraturan Bupati tersebut.

\section{Metode Penelitian}


Penelitian ini menggunakan pendekatan kualitatif dengan jenis penelitian deskriptif. Jenis data yang digunakan dalam penelitian ini meliputi data primer yang dikumpulkan dari situasi aktual, atau data yang diambil ketika peristiwa tersebut terjadi sehingga dinamakan data primer. Atau dengan kata lain, data primer diperoleh secara langsung dan aktual dari sumbernya yang dapat melalui wawancara dan studi dokumen. Selain itu terdapat data sekunder yang merupakan suatu data yang dihasilkan berdasarkan pengumpulan data dari tangan kedua atau dari sumber-sumber lain yang telah tersedia sebelumnya.

Dalam penelitian ini penulis menggunakan wawancara mendalah secara terstruktur dan tidak struktur. Adapun teknik penentuan informan dalam penelitian yang dengan menggunakan teknik purposive sampling, yaitu merupakan suatu teknik pengambilan sampel yang dilakukan secara sengaja. Maksudnya, seorang informan tidak diambil secara acak atau random, akan tetapi ditentukan atau dipilih sendiri oleh peneliti yang bersangkutan atas rasionalisasi atau pertimbangan tertentu. Peneliti memilih informannya berdasarkan kriteria penilaian tertentu yaitu berdasarkan standarisasi peneliti yang telah ditetapkan sesuai dengan topik penelitian yang akan dilakukan. Sedangkan teknik analisis data yang dilakukan adalah dengan teknik hasil reduksi.

\section{Hasil Dan Pembahasan}

Pendidikan adalah bagan dari hak dasar yang mesti diperoleh oleh setiap orang. Pada penelitian ini penulis melakukan penelitian terkait implementasi kebijakan Peraturan Bupati Purwakarta Nomor 69 Tahun 2015 tentang pendidikan karakter khususnya pada aturan terkait jam sekolah yang diterapkan pada siswa di Kabupaten Purwakarta. Untuk menganalisis impelementasi dari kebijakan tersebut, peneliti menggunakan model analisis yang dikenalkan oleh Edward III seperti terdapat dalam Agustino (2008: 149). Berdasarkan hasil observasi adalah sebagai berikut:

\section{Komunikasi}

Variabel komunikasi yang dimaksud dalam hal ini adalah penyampaian informasi kepada masyarakat yang dilakukan oleh pemerintah terkait suatu regulasi atau kebijakan yang akan diterapkan. Pada variabel komunikasi ini terdapat beberapa unsur atau indikator, diantaranya:

a) Transmisi, seringkali terdapat kesalah pahaman (miskomunikasi) dalam proses komunikasi yang salah satu penyebabnya adalah komunikasi yang melewat berbagai tingkatan yang ada dalam birokrasi yang begitu panjang, sehingga komunikasi berjalan tidak sesuai dengan apa yang diharapkan. Artinya komunikasi tersebut terdistorsi di tengah jalannya proses komunikasi. Pada dimensi transmisi ini informasi yang disampaikan bukan hanya untuk para implementor dari kebijakan, namun untuk semua kelompok yang menjadi sasaran dan pihak terkait atas kebijakan yang telah dibuat tersebut. Dalam hal ini, Pergub No. 69 tahun 2015 tentang pendidikan berkarakter mengenai aturan jam sekolah tersebut telah melalui proses panjang. Mulai dari perumusan yang dimana Dinas Pendidikan Pemuda dan Olahraga Kabupaten Purwakarta sebagai penanggung jawab, hingga peraturan tersebut diterapkan.

b) Kejelasan, kejelasan komunikasi sangat diperlukan dalam penyampaian informasi kepada pelaksana agar tidak terdapat kesalah pahaman. Berdasarkan hasil observasi terkait Pergub Purwakarta No. 69 tahun 2015 sampai tahun 2019 ini diketahui dan dipahami dengan jelas baik oleh pelaksana kebijakan, siswa, maupun masyarakat secara umum bahwa tujuan dari dirubahnya aturan jam masuk sekolah yaitu agar terbentuk karakter disiplin para pelajar 
juga sebagai salah satu upaya untuk menghindari kemacetan karena jam masuk sekolah dengan jam kerja sama.

c) Konsistensi, tugas yang diberikan untuk dijalankan melalui komunikasi harus bersifat tetap atau tidak berubah-ubah untuk menghindari timbulnya kebingungan bagi pelaksana di lapangan. Berdasarkan hasil wawancara peneliti dengan Kepala Dinas Pendidikan Purwakarta, ia menjelaskan bahwa setelah kebijakan tersebut selesai direncanakan, pemerintah melakukan sosialisasi terlebih dahulu kepada seluruh kepala sekolah dan pengawas UPTD Kecamatan menjalankan fungsi controling terhadap jalannya kebijakan di setiap sekolah secara jelas. Sosialisasi dilakukan dengan tujuan agar kebijakan yang dibuat dapat mencapai sasaran dari kebijakan tersebut.

Dalam proses sosialisasi kebijakan tersebut, media yang seringkali digunakan adalah media elektronik seperti melalui pemberitaan maupun surat kabar agar masyarakat dapat mengetahui dengan baik. Hal tersebut dibuktikan dengan adanya hasil wawancara antara peneliti dengan orang tua A1 terkait sosialisasi tersebut. Hasil wawancara menunjukkan bahwa ia mengeahui terkait adanya rencana kebijakan tentang aturan jam sekolah yang baru, bahkan ia menyatakan bahwa sebelum kebijakan tersebut di sahkan mereka melakukan rapat orang tua untuk membahas aturan yang baru tersebut. Selain itu, berdasarkan hasil wawancara yang dilakukan peneliti dengan orang tua siswa A2 menunjukkan adanya kesamaan jawaban yakni diadakannya sosialisasi dan rapat antar orang tua telebih dahulu.

Dari hasil wawancara tersebut menunjukkan adanya informasi terlebih dahulu terkait kejelasan dari dibuatnya kebijakan, sehingga informasi disampaikan dengan baik kepada para pelaksana maupun penerima kebijakan. Dengan adanya hal tersebut dapat mengurangi terjadinya miskomunikasi yang akan menyebabkan tidak tercapainya kebijakan. Dapat disimpulkan bahwa Peraturan Bupati Purwakarta No. 60 tahun 2015 tentang pendidikan berkarakter terkait aturan jam sekolah telah dikomunikasikan dengan baik. Sesuai dengan teori yang digunakan yaitu setiap kebijakan yang akan diterapkan dikomunikasikan terlebih dahulu kepada pelaksana kebijakan sehingga tidak terjadi kesalah pahaman ketika pelaksana menyampaikan kepada target atau sasaran dari kebijakan tersebut.

\section{Sumber Daya}

Unsur pelaksana ke dua yang sangat diperlukan keradaannya adalah Sumber Daya. Adanya sumber daya yang kompeten di bidangnya tentu sangat diperlukan. Yang dimaksud dengan sumber daya tersebut adalah:

a) Staff, yaitu berdasarkan hasil wawancara yang peneliti lakukan, ide terkait aturan jam sekolah tersebut pertama kali dikemukakan oleh Bapak Dedi Mulyadi selaku Bupati Purwakarta pada saat itu. Bahkan, setelah pergantian bupati saat ini kebijakan mengenai aturan jam sekolah tersebut masih tetap diberlakukan. Hal tersebut dikarenakan adanya sumber daya staff atau pegawai yang kompeten dalam bidangnya yaitu dalam hal pendidikan berkarakter.

Berdasarkan pemaparan tersebut, dapat disimpulkan bahwa Peraturan Bupati No. 69 tentang pendidikan berkarakter sudah dilaksanakan dengan baik. Berdasarkan teori yang digunakan yaitu suatu kebijakan harus mempunyai sumber daya yang memadai dan kompeten untuk mencapai tujuan dari kebijakan tersebut. Dari hasil wawancara yang dilakukan peneliti dapat dilihat bahwa Pemerintah Kabupaten Purwakarta telah memiliki Sumber Daya staff dan pegawai yang memadai dan kompeten.

b) Informasi, yaitu Kepala Dinas Pendidikan Kabupaten Purwakarta menyebutkan bahwa informasi dari sumber daya mengenai pelaksanaan kebijakan telah disampaikan. Hal tersebut 
dilakukan melalui sosialisasi kepada seluruh kepala sekolah beserta UPTD di Kabupaten Purwakarta. Akan tetapi, mengenai informasi data kepatuhan dalam kebijakan No.68 tahun 2015 tentang pendidikan berkarakter tidak ada, yang ada justru mengenai kebijakan larangan pedagang untuk berjualan di lingkungan sekolah yang diawasi oleh Satpol PP. Sedangkan untuk kebijakan aturan jam masuk sekolah yang diawasi oleh kepala sekolah dan pengawas UPTD, sanksi yang diberikan kepada para pelanggar hanyalah berbentuk peringatan dan tidak ada pencatatan khusus bagi yang datang terlambat.

Hasil dari wawancara menunjukkan bahwa siswa dan guru yang datang terlambat tidak dicatat, mereka hanya diberikan peringatan untuk tidak datang terlambat lagi. Selain itu, siswa dan guru yang datang terlambat sempat diberikan peringatan, akan tetapi untuk sekarang jarang sekali diberikan peringatan. Seringkali guru dan siswa yang terlambat dibiarkan begitu saja. Dari hasil wawancara antara peneliti dengan siswa tersebut menunjukkan bahwa tidak ada data mengenai kepatuhan. Tidak adanya sanksi yang diterapkan terkait kebijakan mengenai perubahan aturan jam sekolah ini membuat guru maupun siswa tetap melanggar, karena tidak dilakukan pencatatan secara formal maupun sanksi yang tegas.

Melihat pada hasil penelitian yang dilakukan, peneliti dapat menyimpulkan bahwasanya berdasarkan teori yang peneliti pakai sebagai alat ukur terkait dimensi sumber daya informasi dari staff belum dilaksanakan dengan baik oleh Pemerintah Kabupaten Purwakarta, yakni dalam hal menjalankan Peraturan Gubernur Nomor 69 Tahun 2015 tentang Pendidikan Berkarakter mengenai aturan jam sekolah. Hal tersebut dikarenakan pemerintah Kabupaten Purwakarta pada hal ini adalah Dinas Pendidikan, tidak memiliki data kepatuhan siswa dan murid yang melanggar aturan. Sehingga hal tersebut menyebabkan suatu kebijakan belum tercapai sesuai dengan tujuan. Selain itu, sanksi yang diterapkan bagi para pelanggar hanya dilaksanakan pada awal penerapan kebijakan saja. Hal tersebut terlihat dari hasil wawancara yang menyebutkan bahwa saat ini, siswa ataupun guru yang melanggar dibiarkan saja tanpa ada sanksi apapun.

c) Wewenang, yaitu berdasarkan hasil wawancara, pelaksanaan kebijakan ini perlu dilakukan oleh sumber daya manusia yang kompeten agar pengembangan karakter yang dilakukan sesuai dengan tujuan atau sasaran yang telah ditentukan. Oleh karena itu, perlu ada pula pihak-pihak yang kompeten pula untuk melakukan fungsi controling terhadap berlangsungnya pengembangan pendidikan berkarakter di Kabupaten Purwakarta. Maka, pihak yang diberikan kewenangan untuk melakukan pengawasan tersebut adalah kepala sekolah, pengawas UPTD di tiap kecamatan, dan Dinas Pendidikan.

Berdasarkan hasil observasi, peneliti dapat simpulkan bahwa terkait dimensi wewenang atau sumber daya wewenang telah dilaksanakan dengan baik sesuai dengan teori yang penulis gunakan untuk mengukur hal tersebut. Hal tersebut ditandai dengan adanya wewenang yang bersifat formal melalui Peraturan Bupati No. 69 tahun 2015 tentang Pendidikan Berkarakter serta adanya pengawasan terhadap jalannya kebijakan tersebut yang dilakukan dengan efektif.

d) Fasilitas, sarana dan prasarana merupakan salah satu pendukung dalam pelaksanaan sebuah kebijakan. Melihat pada hasil dari wawancara yang dilakukan peneliti, dalam penerapan kebijakan tersebut pemerintah Kabupaten Purwakarta tidak menyediakan fasilitas fisik seperti disediakannya bus sekolah. Pemerintah hanya memberikan fasilitas berupa kinerja seperti dilakukannya koordinasi dengan Satpol PP, Dinas Perhubungan, sampai kepolisian untuk mengatur lalu lintas saat jam masuk ataupun jam pulang sekolah.

Untuk itu, dapat disimpulkan pada dimensi fasilitas terkait implementasi Peraturan Bupati No. 69 tahun 2015 ini menunjukkan bahwa pemerintah Kabupaten Purwakarta tidak 
memberikan bantuan berupa sarana prasarana untuk menunjang proses implementasi kebijakan. Sedangkan fasilitas merupakan faktor yang penting untuk mencapai keberhasilan dalam implementasi kebijakan.

\section{Disposisi}

Tidak boleh terjadi kesenjangan antara pembuat dengan implementor kebijakan, sehingga haruslah ada terjalin hubungan yang akan mendukung terlakasananya implementasi kebijakan. Disposisi ini dapat meliputi sikap jujur serta memiliki sikap komitmen terhadap tugas yang telah diterimanya.

Dalam hal ini, pada implementasinya sikap implementor belum mendukung dan menjalankan tupoksinya secara maksimal. Hal tersebut dibuktikan dengan hasil wawancara yang telah peneliti sampaikan sebelumnya, yakni masih adanya guru ataupun murid yang datang terlambat yang dapat memberikan contoh buruk kepada pelajar atau guru lainnya. Ditambah dengan sikap dari kepala sekolah yang bersangkutan, tidak melakukan pengawasan terkait berjalannya kebijakan mengenai aturan jam sekolah ini serta tidak memberikan peringatan kepada para pelanggar. Ada beberapa hal penting yang perlu menjadi perhatian dari variabel disposisi ini, yaitu sebagai berikut:

a) Pengangkatan birokrat, maksudnya dalam pemilihan anggota yang bertugas sebagai pelaksana kebijakan haruslah mereka yang berdedikasi terhadap regulasi yang telah dibuat khususnya terhadap kepentingan masyarakatnya. Hasil observasi menunjukkan bahwa Bapak Dedi Mulyadi merupakan orang yang berdedikasi dalam bidang pendidikan berkarakter. Selain itu, pengangkatan kepala sekolah sebagai orang yang melakukan pengawasan dapat dinilai tepat. Hal tersebut bertujuan agar kepala sekolah dapat mengawasi siswa-siswinya terutama mereka yang sering datang terlambat. Mengacu pada hasil observasi, dapat disimpulkan bahwa dimensi pengangkatan birokrat sudah dilaksanakan dengan baik.

b) Insentif, dengan memanipulasi insentif seperti penambahan keuntungan atau biaya tertentu tidak menutup kemungkinan dapat menjadi faktor pendorong bagi pelaksana kebijakan untuk bekerja dengan lebih baik. Berdasarkan hasil wawancara peneliti dengan kepala dinas pendidikan, beliau menyebutkan bahwa para pelaksana kebijakan tidak diberikan insentif atau diberikan tambahan keuntungan. Beliau mengatakan bahwa Dinas Pendidikan hanya melaksanakan kebijakan sesuai dengan apa yang diperintahkan. Karena pada kebijakan ini hanyalah berisikan perubahan aturan jam sekolah sehingga tidak terdapat anggaran apapun khususnya untuk kepentingan pribadi.

\section{Struktur Birokrasi}

Adanya kesesuaian antara organisasi birokrasi dengan kebijakan yang dibuat inilah yang disebut dengan struktur birokrasi. Yang menjadi tantangan adalah bagaimana cara untuk mencegah terjadinya Bureaucratic Fregmentation. Karena jika hal tersebut terjadi maka akan menjadikan proses implementasi kebijakan tidak efektif. Hal tersebut dikarenakan ada struktur birokrasi yang lemah, meskipun seluruh variabel telah tercapai. Adanya kebijakan sifatnya kompleks mengharuskan adanya kerjasama dengan orang yang banyak, hal tersebut akan menjadi penghambat dari pelaksanaan kebijakan. Birokrasi yang ditugaskan untuk melaksanakan kebijakan dituntut untuk memberikan dukungan terhadap kebijakan yang telah dibuat. Dalam melaksanakan sebuah kebijakan, struktur birokrasi berperan sebagai faktor penting dalam implementasi sebuah kebijakan.

Melihat kepada hasil wawancara yang dilakukan peneliti adalah tidak terdapat koordinasi yang sifatnya lebih spesifik yang dilakukan oleh Dinas Pendidikan terhadap instansi 
lainnya. Akan tetapi, dalam pelaksanaannya terdapat instansi seperti Dinas Perhubungan, Satpol PP, serta kepolisian yang ikut serta untuk mencapaikan tujuan dari kebijakan aturan jam sekolah yang telah dibuat.

Selain itu, adanya Standar Operasional Procedur sebagai acuan atau petunjuk bagi para pelaksana menjadi salah satu aspek yang penting pula. Hal ini dimaksudkan agar setiap implementor yang berperan sebagai pelaksana kebijakan tidak keluar dari sasaran dan tujuan dibuatnya kebijakan. Berdarsarkan hasil observasi, maka struktur birokrasi dalam implementasi Peraturan Bupati dapat dilihat pada penjelasan berikut ini:

1) Secara keseluruhan, pembinaan terhadap kebijakan pendidikan berkarakter dilakukan oleh Bupati Purwakarta. Sedangkan pelaksanaan teknis dilakukan oleh Kepala Dinas Pendidikan Pemuda dan Olahraga.

2) Fungsi dari Dinas Pendidikan Pemuda dan Olahraga yang ditunjuk oleh Bupati sebagai pelaksana teknis adalah sebagai berikut :

a) Kepala Disdikpora ditugaskan untuk melakukan sosialisasi terkait Peraturan Bupati No. 69 ini kepada seluruh penyelenggara pendidikan juga kepada orang tua peserta didik melalui Komite Nasional.

b) Kepala Disdikpora melakukan koordinasi mengenai seluruh kegiatan pengawasan dalam pelaksanaan peraturan.

c) Pengawasan terhadap pelaksanaan kebijakan pendidikan berkarakter di tingkat kabupaten diawasi oleh Kepala Disdikpora, sedangkan di tingkat satuan pendidikan diawasi oleh satuan pendidikan.

d) Evaluasi pelaksanaan kebijakan dan penyamapaian saran perbaikan kepada Bupati, dilakukan oleh Kepala Disdikpora.

Untuk pemberian sanksi bagi para pelanggar menurut Kepala Dinas Pendidikan, yaitu diberikan sanksi berupa peringatan. Berdasarkan hasil wawancara yang peneliti lakukan, dapat disimpulkan yaitu meskipun dalam implementasi Peraturan Bupati Nomor 69 tahun 2015 tentang Pendikan Berkarakter terkait aturan jam masuk sekolah telah terlihat adanya kejelasan mengenai struktur birokrasi, namun instansi yang terlibat seperti Disdik dan Dispora belum menjalankan fungsinya dengan maksimal. Karena salah satu tanda bahwa suatu kebijakan telah dilaksanakan dengan baik adalah terdapat koordinasi yang jelas dan baik terhadap seluruh instansi yang terlibat di dalamnya. Selain itu, harus ada koordnasi yang lebih jelas agar tujuan kebijakan tercapai dengan maksimal.

\section{Simpulan}


Berdasarkan pada hasil dan pembahasan penelitian, dapat disimpulkan bahwa implementasi Peraturan Bupati Purwakarta No. 60 tahun 2015 tentang pendidikan berkarakter terkait aturan jam sekolah pukul 6 pagi belum sepenuhnya baik. Dari empat dimensi implementasi yang ada, hanya dimensi komunikasi yang dijalankan dengan efektif, namun tiga dimensi lainnya belum dilakukan secara optimal. Oleh karena itu, agar implementasi kebijakan tersebut dapat berjalan dengan baik maka perlu dilakukan sejumlah perbaikan. Sejumlah perbaikan tersebut misalnya yaitu optimalisasi ketersediaan sumber daya informasi dan fasilitas, peningkatan aspek pemberian insentif kepada pihak pelaksana program, perbaikan koordinasi antar lembaga yang berkepentingan, dan optimalisasi fungsi dan tugas pokok Dinas.

\section{Referensi}

Afiuddin., Saebani A. B. (2012). Metodelogi Penelitian Kualitatif. Bandung: Pustaka Setia Agustino, L. (2008). Dasar-Dasar Kebijakan Publik. Bandung: Alfabeta

Anggara, S. (2014). Kebijakan Publik. Bandung: Pustaka Setia

Arifin, S, et al. (2010). Model Pendidikan Karakter CAK di ITS menuju Kemudahan Hidup Bermartabat: Strategi Implementasi. Surabaya: Arek ITS CAK

Arikunto, S. (2002). Prosedur Penelitian Suatu pendekatan Praktek. Jakarta: Rineka Cipta

Harbani, P. (2013). Teori Administrasi Publik. Yogyakarta: Alfabeta.

Hasan, S.H, et.al. (2010). Pengembangan Pendidikan Budaya dan Karakter Bangsa. Jakarta: Pusat Kurikulum,Badan Penelitian dan Pengembangan kementerian Pendidikan Nasional

Ismail, N. (2009). Perilaku Administrasi Kajian, Teori Dan Pengantar Praktik. Jakarta: Ghalia Indonesia

Koentjaraningrat. (1999). Metode-Metode Penelitian Masyarakat. Jakarta: Gramedia

Marzuki. (1986). Metodelogi Riset. Yogyakarta: UII Press

Moleong, L.J. (2007). Metodelogi Penelitian Kualitatif. Bandung: Remaja Rosdakarya,

Nasehudin, S.T., Gozali, N. (2012). Metode Penelitian Kualitatif. Bandung: Pustaka Setia

Nawawi, H. (1998). Metode Penelitian Bidag Sosial. Yogyakarta: Gajah Mada University press.

Nugroho, R. (2012). Public Policy for the developing Countries. Yogyakarta: Pustaka Pelajar

Santosa, P. (2014). Administrasi Publik: Teori dan aplikasi Good Governance. Bandung: Reflika Aditama

Silalahi, U. (2012). Metode Penelitian Sosial. Bandung: Reflika Aditama

Sugiyono. (2016). Metode Penelitian Kuantitatif, Kualitatif dan R\&D. Bandung: Alfabeta 